University of Wollongong

Research Online

Australian Institute for Innovative Materials -

Papers

Australian Institute for Innovative Materials

$1-1-2016$

Conductive and protein resistant polypyrrole films for dexamethasone delivery

Binbin Zhang

University of Wollongong, binbinz@uow.edu.au

Paul J. Molino

University of Wollongong, pmolino@uow.edu.au

Alexander R. Harris

University of Wollongong, alexh@uow.edu.au

Zhilian Yue

University of Wollongong, zyue@uow.edu.au

Simon E. Moulton

University of Wollongong, smoulton@uow.edu.au

See next page for additional authors

Follow this and additional works at: https://ro.uow.edu.au/aiimpapers

Part of the Engineering Commons, and the Physical Sciences and Mathematics Commons

Research Online is the open access institutional repository for the University of Wollongong. For further information contact the UOW Library: research-pubs@uow.edu.au 


\title{
Conductive and protein resistant polypyrrole films for dexamethasone delivery
}

\begin{abstract}
The development of inherently conducting polymers as controllable/programmable drug delivery systems has attracted significant interest in medical bionics, and the interfacial properties of the polymers, in particular, protein adsorption characteristics, is integral to the stability of the overall performance. Herein we report a hybrid conducting system based on polypyrrole doped with an anti-inflammatory prodrug, dexamethasone phosphate (DexP), upon which post-surface modification was conducted to render the polymer more biostable. We firstly investigated the influence of the current density and DexP concentration on the physiochemical properties and surface characteristics of the resulting polymer films. Films were then surface modified with thiolated poly(ethylene glycol). The influence of surface modification on inhibition of nonspecific protein adsorption to the polymer surfaces was evaluated using electrochemistry and quartz crystal microbalance. Furthermore, studies were undertaken to examine the effect of surface coatings on the drug release behaviour triggered by electrical stimulation. Our results demonstrated that both the physiochemical and interfacial properties of conducting polymers can be modulated to enhance the performance of the materials as biocompatible drug delivery systems. This provides important insight into molecular engineering of conducting polymers to facilitate their applications in medical bionics.
\end{abstract}

\section{Keywords}

dexamethasone, films, delivery, polypyrrole, conductive, resistant, protein

Disciplines

Engineering | Physical Sciences and Mathematics

\section{Publication Details}

Zhang, B., Molino, P. J., Harris, A. R., Yue, Z., Moulton, S. E. \& Wallace, G. G. (2016). Conductive and protein resistant polypyrrole films for dexamethasone delivery. Journal of Materials Chemistry B, 4 (15), 2570-2577.

\section{Authors}

Binbin Zhang, Paul J. Molino, Alexander R. Harris, Zhilian Yue, Simon E. Moulton, and Gordon G. Wallace 


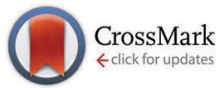

Cite this: J. Mater. Chem. B, 2016, 4, 2570

Received 30th March 2015, Accepted 5th March 2016

DOI: $10.1039 / c 5 t b 00574 d$

www.rsc.org/MaterialsB

\section{Conductive and protein resistant polypyrrole films for dexamethasone delivery}

\author{
B. Zhang, P. J. Molino, A. R. Harris, Z. Yue, S. E. Moulton* $†$ and G. G. Wallace*
}

The development of inherently conducting polymers as controllable/programmable drug delivery systems has attracted significant interest in medical bionics, and the interfacial properties of the polymers, in particular, protein adsorption characteristics, is integral to the stability of the overall performance. Herein we report a hybrid conducting system based on polypyrrole doped with an anti-inflammatory prodrug, dexamethasone phosphate (DexP), upon which post-surface modification was conducted to render the polymer more biostable. We firstly investigated the influence of the current density and DexP concentration on the physiochemical properties and surface characteristics of the resulting polymer films. Films were then surface modified with thiolated poly(ethylene glycol). The influence of surface modification on inhibition of nonspecific protein adsorption to the polymer surfaces was evaluated using electrochemistry and quartz crystal microbalance. Furthermore, studies were undertaken to examine the effect of surface coatings on the drug release behaviour triggered by electrical stimulation. Our results demonstrated that both the physiochemical and interfacial properties of conducting polymers can be modulated to enhance the performance of the materials as biocompatible drug delivery systems. This provides important insight into molecular engineering of conducting polymers to facilitate their applications in medical bionics.

\section{Introduction}

Inherently conducting polymers (ICPs) have attracted significant interest in the area of biomaterials development due to their inherent biocompatibility and their ability to perform multiple biologically relevant functions. ${ }^{1-4}$ Research has been particularly focused on the use of ICPs in medical bionic devices, such as the cochlear implant, which is attributable to their low impedance, ability to record or apply electrical stimuli to promote cell survival, growth and differentiation, and the unique capability to perform electrochemically controlled drug delivery. ICPs can be used for controlled drug delivery systems through the redox mechanism that ICPs exhibit under electrical stimulation. ICPs incorporate anions into their backbone structures during electropolymerisation, which is called "doping", and the incorporated anions are called "dopants". After electropolymerisation, when a reduction potential is applied, the ICPs are able to eject the doped anions, if they are suitably small enough to be expelled from the polymer matrix. This mechanism therefore can be employed for controlled release of anion drugs. ${ }^{5}$

ARC Centre of Excellence for Electromaterials Science, Intelligent Polymer Research Institute, AIIM Faculty, Innovation Campus, University of Wollongong, NSW 2500, Australia. E-mail: gwallace@uow.edu.au

$\dagger$ Current address: Biomedical Engineering, Faculty of Science, Engineering and Technology, Swinburne University of Technology, Hawthorn, VIC, 3122, Australia.
While ICPs show enormous promise in medical bionics, a number of key challenges are yet to be addressed in order to maximise their performance in vivo. One challenge is to tune their biocompatibility and functionality for specific applications by modulating the material physical (i.e. modulus, interfacial roughness) and chemical (monomer, dopant species, interfacial chemistry) properties, providing a tailored polymer best suited for the final application. Another major challenge is to combat the adverse host tissue reactions associated with implantation, including foreign body and inflammatory responses, where nonspecific protein adsorption to the device surface serves as a key trigger, in addition to other factors such as tissue damage during implantation and mechanical mismatch between the devices and the surrounding tissues. ${ }^{6-8}$ It is well known that proteins adsorb to a biomaterial surface within seconds of contact. ${ }^{9}$ Both the composition of the adsorbed protein layer, as well as the conformation of the surface bound protein molecules, can act in concert to promote foreign body and inflammatory responses through facilitating a range of biochemical cascades that may act upon surrounding cellular and tissue function, as well as initiate reactions from cells and tissues in direct contact with the biomaterial itself. ${ }^{8}$ This can ultimately lead to device failure and unexpected risks for patients. ${ }^{10}$ Critical to controlling inflammatory and foreign body response to implanted materials is to develop surface coatings that minimize non-specific protein interaction at the biomaterial interface. 
In this study, a multifunctional polypyrrole based system has been developed to electrochemically deliver the anti-inflammatory prodrug, dexamethasone phosphate. In addition, this system was modified to improve the surface resistance to nonspecific protein adsorption, which, in concert with subsequent fibrotic tissue growth that can adversely affect biomaterials after surgery, can impede the release and delivery of drug from the device to the intended tissues. We investigated different conditions for the electropolymerisation of dexamethasone sodium phosphate doped polypyrrole (PPy/DexP) films, and their impacts on the physiochemical properties and the electrically-stimulated drug release profiles of the resulting polymer films. Poly(ethylene glycol)methyl ether thiol (PEG-SH) of different molecular weights were then employed to modify the PPy/DexP film surface. Quartz crystal microbalance (QCM) was used to study the PEGylation, as well as fibrinogen interaction with PPy/DexP films prior to and after surface modification.

\section{Material and methods}

\section{Materials}

Pyrrole was purchased from Merck (Australia), and was distilled and stored at $-20{ }^{\circ} \mathrm{C}$ before use. Dexamethasone sodium phosphate was purchased from Spectrum Chemical Mfg. Corp. (New Brunswick, NJ). Poly(ethylene glycol)methyl ether thiol, $M_{\mathrm{W}} 5000 \mathrm{Da}$ (PEG 5k) \& 40000 Da (PEG 40k), was purchased from Jenkem (USA). Fibrinogen was purchased from SigmaAldrich (Australia). All the other chemicals listed in this research were from Ajax (Australia) and used as purchased.

\section{Preparation of PPy/DexP by electropolymerisation}

Monomer solutions were freshly prepared prior to electropolymerisation. DexP solutions were prepared in deionised water and then deoxygenated for $30 \mathrm{~min}$ via bubbling with nitrogen gas, followed by the addition of pyrrole to produce $0.2 \mathrm{M}$ monomer solutions.

Gold-coated Mylar films were cut into $1 \mathrm{~cm}$ wide stripes and were cleaned with ethanol in a sonicating bath, then rinsed with ethanol and deionised water and dried under nitrogen gas. The strips were masked to leave a reactive area of $1 \mathrm{~cm}^{2}$ at one end.

$\mathrm{PPy} /$ DexP films were electropolymerised in a three-electrode electrochemical cell, consisting of a $\mathrm{Ag} / \mathrm{AgCl}$ reference electrode, a platinum mesh counter electrode and gold-coated Mylar as the working electrode. The electrochemical cell was connected to an eDAQ potentiostat and controlled by eDAQ Chart software. PPy/DexP films were grown by galvanostatic deposition to a total charge density of $1 \mathrm{C} \mathrm{cm}^{-2}$. Experimental conditions were applied as shown in Table 1.

\section{Surface modification with poly(ethylene glycol)methyl ether thiol (PEG-SH)}

The thiol groups in PEG-SH have been demonstrated to react with the PPy backbone via a thiol-ene reaction, forming a covalent bond, and therefore changing the surface properties of PPy films (eqn (1)). ${ }^{11}$
Table 1 Electrochemical synthesis conditions for PPy/DexP films

\begin{tabular}{llll}
\hline PPy/DexP film & $\begin{array}{l}\text { DexP } \\
\text { concentration }(\mathrm{mM})\end{array}$ & $\begin{array}{l}\text { Current density } \\
\left(\mathrm{mA} \mathrm{cm}^{-2}\right)\end{array}$ & $\begin{array}{l}\text { Growth } \\
\text { time }(\mathrm{s})\end{array}$ \\
\hline A: $5 \mathrm{mM} / 0.5 \mathrm{~mA}$ & 5 & 0.5 & 2000 \\
B: $5 \mathrm{mM} / 1.0 \mathrm{~mA}$ & 5 & 1.0 & 1000 \\
C: $5 \mathrm{mM} / 1.5 \mathrm{~mA}$ & 5 & 1.5 & 667 \\
D: $10 \mathrm{mM} / 1.5 \mathrm{~mA}$ & 10 & 1.5 & 667 \\
E: $15 \mathrm{mM} / 1.5 \mathrm{~mA}$ & 15 & 1.5 & 667
\end{tabular}

In this study, PEG-SHs with two different molecular weights (PEG 5k and PEG 40k) were assessed for surface modification. PPy films were treated with PEG-SH by submerging each film and supporting substrate in a $0.1 \mathrm{mM}$ PEG-SH solution or by passing the PEG-SH solution across the film surface in a flow chamber for 30 minutes. After the PEG-SH treatment, the films were rinsed thoroughly with deionised water and dried under nitrogen gas for further characterisation.

\section{Quartz crystal microbalance (QCM) characterisation}

Two different QCM systems were employed in this study: an Electrochemical QCM (EQCM) (Stanford Research Systems QCM200), and a QCM with Dissipation monitoring (QCM-D) Q-Sense E4 system (Q-Sense AB, Västra, Frölunda, Sweden).

EQCM was employed to characterise the mass and mechanical properties of the PPy/DexP films as a function of electropolymerisation conditions in situ. The QCM-D system was used to examine the PEG-SH modification and its influence on protein adsorption onto the polymer films through its flow modules. The Stanford Research Systems (SRS) EQCM employed allows the measurement of two parameters: the frequency $(f)$ and the resistance $(R)$. While the frequency provides a measure of the mass adsorbed to the sensor surface, the resistance, which is closely related to the dissipation $(D)$ measurement parameter that is available on more modern QCM-D systems, provides a measure of the viscoelastic, or mechanical properties, of the adsorbed mass. ${ }^{12-14}$ The Sauerbrey model was employed to quantify the mass of polymer deposited on each QCM sensor.

The SRS QCM200 was used in conjunction with an eDAQ potentiostat to monitor the mass deposition during electropolymerisation of PPy/DexP. Chromium/gold coated quartz crystals (5 MHz, $25.4 \mathrm{~mm}$ in diameter) were used. The gold electrode surface was cleaned with ethanol prior to experiments. A threeelectrode electrochemical cell was set up in the vial at the end of the QCM probe and approximately $4 \mathrm{~mL}$ of fresh monomer solution was added in the vial for each polymerisation.

The QCM-D sensor (QSX301) (4.95 MHz $\pm 50 \mathrm{kHz}, 14 \mathrm{~mm}$ in diameter) was cleaned by incubating in a Piranha solution (concentrated sulphuric acid:30\% hydrogen peroxide $(7: 3)$ ) for 3 minutes and rinsed thoroughly with deionised water and dried under a stream of nitrogen gas. The QCM-D quartz crystal sensor was then deposited with a PPy/DexP layer used as the working electrode in a three-electrode electrochemical cell. After polymerisation, the QCM-D sensor was removed from the electrochemical cell and rinsed with deionised water and dried with nitrogen gas. 


\section{Surface modification of PPy/DexP coatings with PEG-SH characterised by QCM}

PPy/DexP coated QCM-D sensors were transferred into the Q-Sense axial flow module (QFM401) and equilibrated in deionised water for 24 hours at a controlled temperature of $22{ }^{\circ} \mathrm{C} \pm 0.02{ }^{\circ} \mathrm{C}$, with deionised water flowed through the chamber at a constant rate of $10 \mu \mathrm{L} \mathrm{min}{ }^{-1}$. Films were equilibrated for such a period of time to allow the frequency $(f)$ and dissipation $(D)$ to stabilise as the gradual hydration of the conducting polymer layer causes the $f$ and $D$ to drift. Once stable, an aqueous $0.1 \mathrm{mM}$ solution of PEG-SH was introduced into the axial flow chamber at a constant rate of $10 \mu \mathrm{L} \mathrm{min}{ }^{-1}$ for 30 minutes where $f$ and $D$ reached equilibrium. Thereafter the chamber was rinsed with deionised water at the same flow rate until the $f$ and $D$ stabilised again. All experiments were undertaken in triplicate.

\section{Protein adsorption characterised by QCM}

Fibrinogen $(\mathrm{Fb})$ from human plasma was used as a model protein for the following protein adsorption experiments. An Fb solution, $0.5 \mathrm{mg} \mathrm{mL} \mathrm{m}^{-1}$ in $0.9 \% \mathrm{NaCl}$ solution, was freshly prepared for each experiment. For the study of protein adsorption on the PPy/DexP surface, PPy/DexP coated QCM-D sensors were transferred into a Q-Sense axial flow module (QFM401) and equilibrated with 0.9\% $\mathrm{NaCl}$ solution for 24 hours at $22{ }^{\circ} \mathrm{C} \pm 0.02{ }^{\circ} \mathrm{C}$ and at a flow rate of

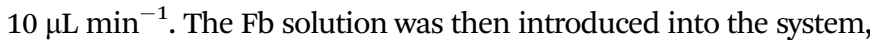
at the same flow rate for 30 minutes. Thereafter the chamber was rinsed with $0.9 \% \mathrm{NaCl}$ solution until the $f$ and $D$ stabilised.

For the study of protein adsorption on PEGylated PPy/DexP surface, subsequent to the PEG-SH modification as described in the previous section, the QCM-D monitoring was continued with the same procedure as described above.

\section{Drug release}

Electrically stimulated drug release was carried out in $3 \mathrm{~mL}$ artificial perilymph (comprising $7.39 \mathrm{~g} \mathrm{~L}^{-1} \mathrm{NaCl}, 0.35 \mathrm{~g} \mathrm{~L}^{-1}$ $\mathrm{KHCO}_{3}, 2.02 \mathrm{~g} \mathrm{~L}^{-1} \mathrm{NaHCO}_{3}, 0.08 \mathrm{~g} \mathrm{~L}^{-1} \mathrm{CaCl}_{2}$ and $0.61 \mathrm{~g} \mathrm{~L}^{-1}$ $\mathrm{NH}_{2} \mathrm{C}\left(\mathrm{CH}_{2} \mathrm{OH}\right)_{3}$, with $\mathrm{pH}$ adjusted to 7.4) in the three-electrode cell. During stimulated release, a constant negative potential $(-500 \mathrm{mV})$ was applied to the polymer films. A $1 \mathrm{~mL}$ aliquot of the release medium was withdrawn at each time point and replaced with $1 \mathrm{~mL}$ of fresh artificial perilymph. The collected samples were tested with a Shimadzu UV-1600 UV-visible spectrophotometer. Spectrum measurements were performed, and the peak absorbance at $242 \mathrm{~nm}$ was recorded for quantification of the amount of DexP released.

\section{Surface characterisation}

Film topography and surface roughness was characterised with an Atomic Force Microscopy (AFM) (Asylum Research MFP 3D SA). Images were obtained in air using intermittent contact mode with a $10 \mu \mathrm{m} \times 10 \mu \mathrm{m}$ scanning area. Roughness and total surface area were calculated using Gwyddion SPM software (version 2.34).

\section{Electrochemistry}

Electrochemistry was performed with a CHI660D potentiostat (CH Instruments, Inc. USA) using a three-electrode set-up in artificial perilymph. Cyclic voltammetry (CV) was carried out between $-0.8 \mathrm{~V}$ and $0.8 \mathrm{~V}$ at a scan rate of $10 \mathrm{mV} \mathrm{s}^{-1}$, with the initial potential at $0 \mathrm{~V}$.

\section{Statistical analysis}

Data are expressed as mean $\pm 95 \%$ confidence interval, and statistical analyses were performed with one-way ANOVA using Minitab 17.

\section{Results and discussion}

\section{Effect of growth condition on PPy/DexP films}

Growth conditions and electrochemical properties. Two sets of growth conditions were investigated for their influence on a range of polymer physiochemical and electrochemical properties, as well as drug release profiles. The influence of current density for electropolymerisation was studied by keeping a constant DexP concentration of $5 \mathrm{mM}$ while varying the current density from $0.5 \mathrm{~mA} \mathrm{~cm}^{-2}$ to $1.5 \mathrm{~mA} \mathrm{~cm}^{-2}$ (Table $1, \mathrm{~A}-\mathrm{C}$ ). The influence of DexP concentration was studied by using a constant current density of $1.5 \mathrm{~mA} \mathrm{~cm}^{-2}$, while varying the DexP concentration from $5 \mathrm{mM}$ to $15 \mathrm{mM}$ (Table 1, C-E). The above electropolymerisation conditions produced 5 unique film compositions in total, as summarised in Table 1.

$\mathrm{CV}$ analysis of PPy/DexP in artificial perilymph electrolyte (Fig. 1) demonstrated a reduction peak shift between the first cycle and second cycle, with the peaks staying constant in the following cycles. This indicated that the complete exchange of dopants during the first cycle. Based on the CV results, a negative potential of $-500 \mathrm{mV}$ was chosen for the stimulated drug release.

Mass deposition and mechanical properties. As shown in Fig. 2A, when the DexP concentration was maintained at $5 \mathrm{mM}$, there was no significant difference $(p>0.1)$ in the total mass of the films deposited on the QCM sensor as a function of the current density. All the films were grown to the same charge density $\left(1 \mathrm{C} \mathrm{cm}^{-2}\right)$, and therefore it would be expected that there would be little variation in the polymer mass as a function of current density. While total film mass did not vary as a function of the current density, it did vary as a function of the concentration of the dopant DexP in the polymerisation solution $(p<0.005)$ (Fig. 2A). The mass of PPy/DexP increased

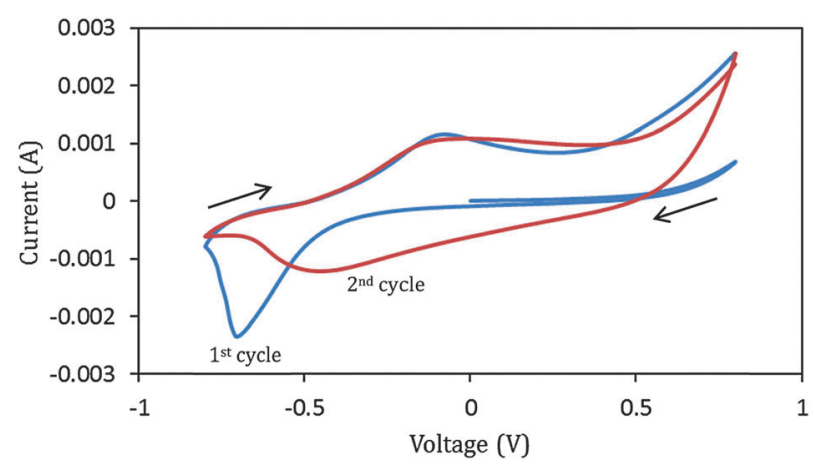

Fig. 1 Cyclic voltammetry of $5 \mathrm{mM} / 0.5 \mathrm{~mA}$ PPy/DexP films, performed in artificial perilymph at a scan rate of $10 \mathrm{mV} \mathrm{s}^{-1} \mathrm{vs}$. Ag/AgCl. 
(A)

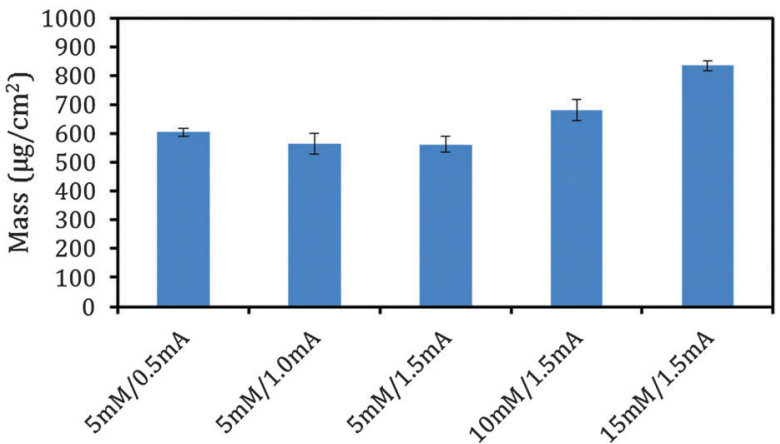

(B)

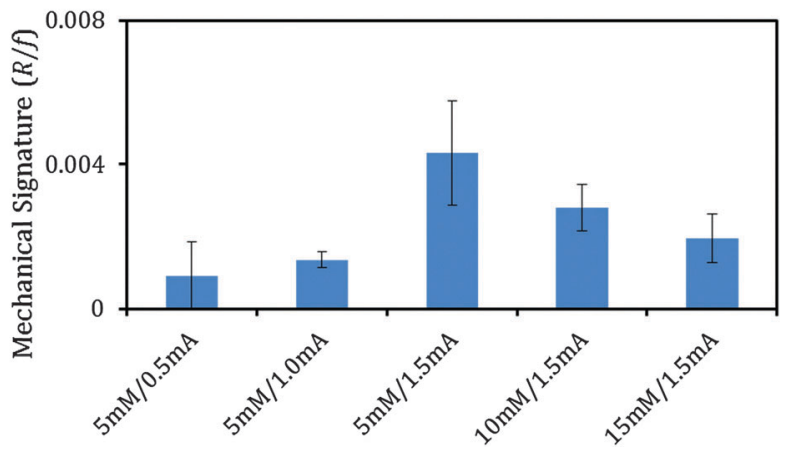

Fig. 2 Mass deposition (A) and mechanical properties (B) of the PPy/DexP films electropolymerised at different current densities and DexP concentrations, measured with EQCM. $n=3$, error bars are representative of $95 \%$ confidence intervals around the mean.

with an increase in DexP concentration, with a DexP concentration of $15 \mathrm{mM}$ yielding the greatest film mass $\left(843 \pm 16 \mu \mathrm{g} \mathrm{cm}^{-2}\right)$. This is likely due to the physical encapsulation of the dopant anions during the polymerisation of PPy on the working electrode. The higher the concentration of DexP in the polymerisation solution, the greater the amount of DexP physically trapped in the polymer matrix. ${ }^{15}$ This phenomenon has been described previously for PPy doped with the large polyanion dextran sulphate (DS), where an increase in the concentration of DS from $0.2 \mathrm{mg} \mathrm{mL}^{-1}$ to $20 \mathrm{mg} \mathrm{mL}^{-1}$ resulted in a significant increase in total polymer mass, and was attributed to physical entrapment of the polyanion, as opposed to an increased degree of doping of the PPy. ${ }^{16}$

A difference in the mechanical properties of the films was observed even though the total film mass did not vary as a function of the current density. The mean mechanical signature, defined as the ratio of the viscoelastic properties of the adsorbed mass (resistance) per unit of adsorbed mass (frequency) $(R / f)$, increased with increasing current density (Fig. 2B). As this ratio increases, the adsorbed mass is deemed more viscoelastic, or more hydrated and soft. ${ }^{17}$ The $R / f$ ratio of the films grown at $1.5 \mathrm{~mA} \mathrm{~cm}{ }^{-2}$ was significantly greater than those grown at $1.0 \mathrm{~mA} \mathrm{~cm}^{-2}$ and $0.5 \mathrm{~mA} \mathrm{~cm}^{-2}$.

The mechanical properties of the PPy/DexP films were also found to vary as a function of the dopant DexP concentration. The viscoelasticity of the polymer films grown at a DexP concentration of $15 \mathrm{mM}$ demonstrated a considerable decrease in viscoelasticity compared to $5 \mathrm{mM}$ and $10 \mathrm{mM}$. The films grown at $1.5 \mathrm{~mA} \mathrm{~cm}^{-2}$ demonstrated overall higher mechanical signature values than those grown at lower current densities.

Film topography. The surface roughness of PPy/DexP film increased with an increase in current density ( $p<0.005)$ (Fig. 3), and decreased with an increase in the concentration of the dopant DexP in the monomer solutions $(p<0.05)$. Films grown at $1.5 \mathrm{~mA} \mathrm{~cm}{ }^{-2}$ with a DexP concentration of $5 \mathrm{mM}$ demonstrated the greatest surface roughness $(203 \pm 8.8 \mathrm{~nm})$.

An increase in current density has previously been shown to increase polymer surface roughness, ${ }^{18,19}$ with this relationship also seen in this system. However, the specific influence of a counterion on polymer properties is known to be highly dependent on the nature of the anion employed during polymer synthesis. ${ }^{20}$ Herein surface roughness was found to significantly

(A)

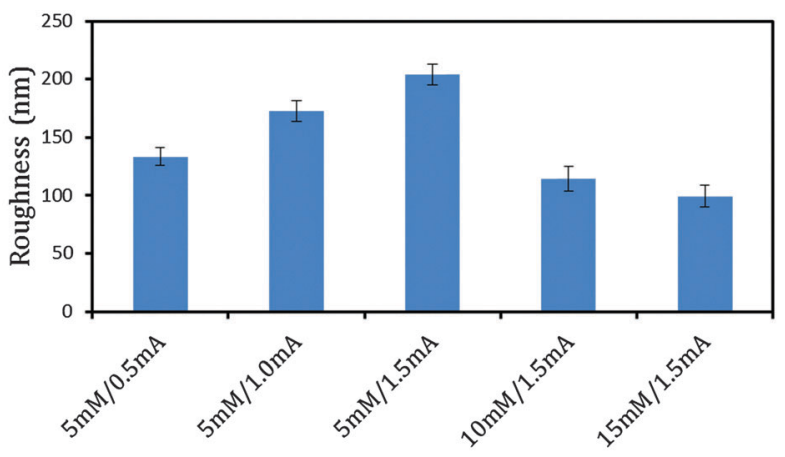

(B)

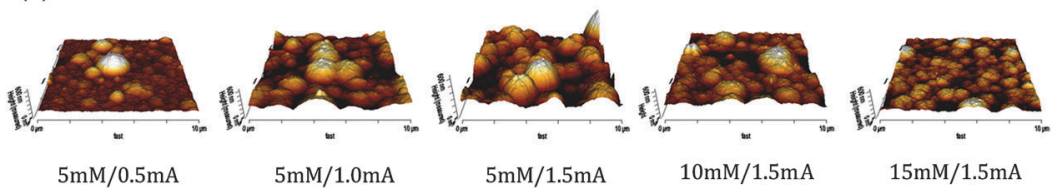

Fig. 3 Roughness (A) and AFM images (B) of PPy/DexP films electropolymerised at different current densities and DexP concentrations. $n=3$, error bars are representative of $95 \%$ confidence intervals around the mean. 


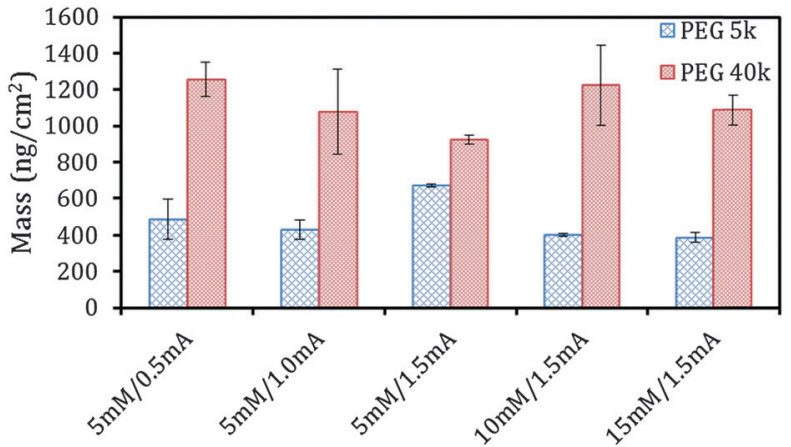

Fig. 4 PEG-SH modification of PPy/DexP films, with either PEG 5k or PEG $40 \mathrm{k} . n=3$, error bars are representative of $95 \%$ confidence intervals around the mean.

decrease with the increasing DexP concentration. This is consistent with a recent study using the biological dopant DS which demonstrated a decreased surface roughness and film thickness with increasing DS concentration, ${ }^{17}$ however contrary to the previous studies that have reported an increased surface roughness of conducting polymer as a result of increasing the dopant concentration, such as $p$-toluene sulfonate and polystyrenesulfonate. ${ }^{21,22}$

The increased roughness obtained from increasing the current density could be correlated to the increase of the $R / f$ ratio in Fig. 2, indicating an increase in viscoelasticity and hydration of the films. This was coincident with the decreased roughness from the reduced viscoelasticity after increasing the dopant concentration, which indicated that the higher dopant concentration in the monomer solution produced denser and smoother films, behaviour that has also been observed in similar studies elsewhere. ${ }^{16}$

\section{Surface modification of PPy/DexP with PEG-SH}

The as-prepared PPy/DexP films were surface modified with PEG-SH, and the resulting mass changes are illustrated in Fig. 4, which was normalised by respective polymer surface area that was quantified using 3D AFM topographic images (Table 2). Firstly, for all the films examined, PEGylation with PEG 40k resulted in a larger mass change compared to those by PEG 5k, which is indicative of more densely packed and/or thicker PEG coating as a result of increased PEG-SH molecular weight. When PEG 5k was employed for PEGylation, the amount of surface anchored PEG increased with an increase

Table 2 Increase in the surface area of the PPy/DexP films compared to the geometric AFM scan area

\begin{tabular}{llllll}
\hline & $5 \mathrm{mM} /$ & $5 \mathrm{mM} /$ & $5 \mathrm{mM} /$ & $10 \mathrm{mM} /$ & $15 \mathrm{mM} /$ \\
PPy/DexP films & $0.5 \mathrm{~mA}$ & $1.0 \mathrm{~mA}$ & $1.5 \mathrm{~mA}$ & $1.5 \mathrm{~mA}$ & $1.5 \mathrm{~mA}$ \\
\hline Surface area & $102.5 \%$ & $104.2 \%$ & $105.9 \%$ & $102.8 \%$ & $102.6 \%$
\end{tabular}

Eqn (1) polypyrrole reaction with thiol group. ${ }^{11}$

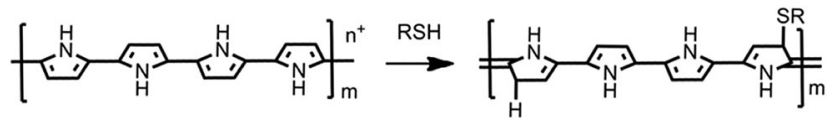

in the current density applied for electropolymerisation of PPy/DexP films, but decreased with an increase in the dopant concentration during electropolymerisation $(p<0.05)$. However, there was no significant difference in the mass deposited on the PPy/DexP films when PEG 40k was used for PEGylation $(p>0.05)$.

For the PEG 5k, an increase in PPy/DexP film roughness was generally associated with an increase in PEG binding, with greatest mass binding illustrated on $5 \mathrm{mM} / 1.5 \mathrm{~mA}$ films, followed by films grown at the lower current densities $(5 \mathrm{mM}$ / $0.5 \mathrm{~mA}$ and $5 \mathrm{mM} / 1.0 \mathrm{~mA}$ ), with the films demonstrated the lowest roughness values $(10 \mathrm{mM} / 1.5 \mathrm{~mA}$ and $15 \mathrm{mM} / 1.5 \mathrm{~mA})$ revealing the least PEG binding. The opposite trend was evident for the PEG 40k, with the least mean PEG binding on the roughest film ( $5 \mathrm{mM} / 1.5 \mathrm{~mA})$, however, there was no significant difference in PEG 40k binding for films grown under all growth conditions $(p>0.05)$.

\section{Protein adsorption on the PPy/DexP and PEGylated PPy/DexP films}

Protein adsorption onto the PPy/DexP films was evaluated using $\mathrm{Fb}$ as a model protein, and using the QCM-D flow modules. The mass adsorbed to the polymer surface was normalised by the polymer surface area that was quantified using 3D AFM topographic images (Table 2).

PEGylation of the PPy/DexP films, using either PEG 5k or PEG 40k, substantially reduced $\mathrm{Fb}$ adsorption at the polymer surfaces, as compared to each respective unmodified PPy/DexP films that were prepared under the various growth conditions (Fig. 5), except for $10 \mathrm{mM} / 1.5 \mathrm{~mA}$ and $15 \mathrm{mM} / 1.5 \mathrm{~mA}$ films modified by PEG $5 \mathrm{k}(p>0.05)$. For the films grown in $5 \mathrm{mM}$ DexP but at various current densities, mean $\mathrm{Fb}$ adsorption was the least for both $5 \mathrm{k}$ and 40k PEGylated PPy/DexP prepared at $1.0 \mathrm{~mA} \mathrm{~cm}{ }^{-2}\left(423 \pm 279 \mathrm{ng} \mathrm{cm} \mathrm{cm}^{-2}\right.$ and $363 \pm 267 \mathrm{ng} \mathrm{cm}{ }^{-2}$ for films modified with PEG 5k and PEG 40k, respectively). For the films grown at a constant current density of $1.5 \mathrm{~mA} \mathrm{~cm} \mathrm{~cm}^{-2}$ but with various DexP concentrations, PEGylation with PEG 40k resulted in a much more pronounced reduction in Fb adsorption $(p<0.005)$, compared to those with PEG 5k. Amongst

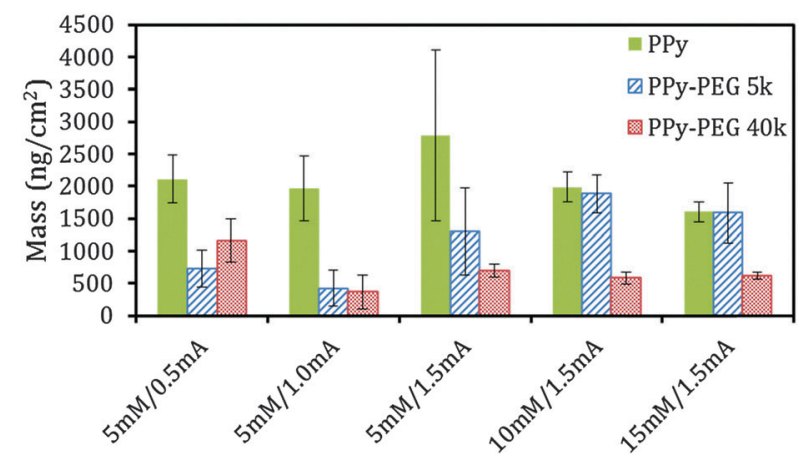

Fig. 5 Fibrinogen protein adsorption against control PPy/DexP films and PEGylated PPy/DexP films with PEG 5k and PEG 40k, measured with QCM-D. $n=3$, error bars are representative of $95 \%$ confidence intervals around the mean. 
all the PEGylated polymer samples, PEG 40k modified films demonstrated a consistent reduction in protein adsorption for all polymerisation conditions, while PEG 5k modified films showed no discernible reduction in protein adsorption for films grown with $10 \mathrm{mM}$ and $15 \mathrm{mM}$ DexP.

PEGylation has been widely employed as a method through which to protect a surface from non-specific protein interactions. The anchored PEG molecules are known to function collectively as a highly hydrated, mobile and conformationally dynamic polymer brush layer, which presents an inert and steric exclusion zone to the surrounding environment. ${ }^{23-25}$ A number of variables have been demonstrated to be critical to optimising the efficacy of the PEG layer to dissuade surface protein interactions, including PEG surface grafting density and the intermolecular interactions/organisation of the PEG chains, which in concert influences both surface coverage and PEG polymer brush conformation at the substrate surface. ${ }^{26-28}$

The reactive binding of PEG-SH to PPy/DexP was characterised as a function of PEG molecular weight, the current density employed during polymer polymerisation, and the concentration of the dopant DexP in the polymerisation electrolyte (Fig. 4). The mass of PEG-SH binding was greater for PEG 40k, relative to the PEG 5k; however, this is less than an 8 to 1 ratio that would be expected from the difference in PEG molecular weight if the overall binding densities were the same. Therefore it can be proposed that the binding density is likely to be substantially less for the larger molecular weight PEG-SH, where repulsive steric interactions for the larger molecular weight PEG-SH prevent high surface binding densities, compared to the smaller PEG 5k. A similar mechanism has previously been proposed to underlie the differences in total PEG-SH binding of PEG-SH to PPy/DS films as measured via QCM-D. $^{17}$

Surface adsorbed PEG at low densities is proposed to present a mushroom type conformation on the surface, conformationally uninhibited by neighbouring PEG molecules. In this regime, neighbouring PEG molecules and their highly hydrated solvation shell are not forced to overlap, and therefore there remain gaps between the surface adsorbed PEG chains through which suitably sized proteins may navigate to reach the underlying polymer surface, drawn by attractive forces including van der Waals, electrostatic and hydrophobic interactions. Additionally, the mushroom-like conformation of PEG acts to minimise the distance between the top of the PEG brush polymer and the surface, and therefore this distance may not be sufficient to impede attractive forces between proteins in the interacting solution and the underlying substratum. Increasing the PEG density on the surface decreases the space between the PEG chains, forcing neighbouring PEG polymer brushes to interact and overlap. Meanwhile, the repulsive intermolecular interactions of the PEG chains forces the PEG molecules away from each other, driving the surface bound PEG chain to extend away from the substratum surface. The elongation of the PEG chain forces a regime shift from a mushroom to a brush type conformation. ${ }^{29}$ In this organisation, PEG density on the surface is increased, reducing the likelihood of gaps between the PEG brush layer, as well as increasing the overall height of the PEG brush layer from the substratum surface. Increasing the molecular weight of surface bound PEG, and therefore increasing the overall chain length, has also been demonstrated to enhance the protein resistant properties of surface bound PEG layers, and is thought to act by increasing the overall thickness of the PEG bound layer, and therefore sterically hindering potential adsorbent protein molecules from reaching the underlying surface. $^{29}$

\section{Drug release studies}

DexP release profiles during the 4 hours stimulation are demonstrated in Fig. 6, among which the $5 \mathrm{mM} / 1.5 \mathrm{~mA}$ films illustrated the most DexP release. At the end of the $4 \mathrm{~h}$ stimulation, the $5 \mathrm{mM} / 1.5 \mathrm{~mA}$ films released a mean value of $242.0 \mu \mathrm{g} \mathrm{cm}^{-2}$ of DexP, while the $5 \mathrm{mM} / 0.5 \mathrm{~mA}$ and $5 \mathrm{mM} /$

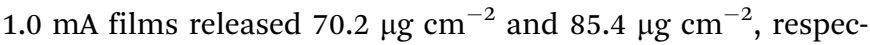
tively. The $10 \mathrm{mM} / 1.5 \mathrm{~mA}$ and $15 \mathrm{mM} / 1.5 \mathrm{~mA}$ films released $108.4 \mu \mathrm{g} \mathrm{cm}^{-2}$ and $82.1 \mu \mathrm{g} \mathrm{cm}^{-2}$ of DexP respectively, which is much less than the $5 \mathrm{mM} / 1.5 \mathrm{~mA}$ films. This result correlates to the results in the roughness and mechanical properties of the PPy/DexP films. The $5 \mathrm{mM} / 1.5 \mathrm{~mA}$ PPy/DexP film is shown to have the highest surface roughness and highest $R / f$ ratio. An increase in surface roughness and viscoelasticity is characteristic of a more porous and hydrated polymer film, relative to other growth conditions. This may promote the interaction with the electrolyte solution, and facilitate the elution of DexP molecules from the bulk film.
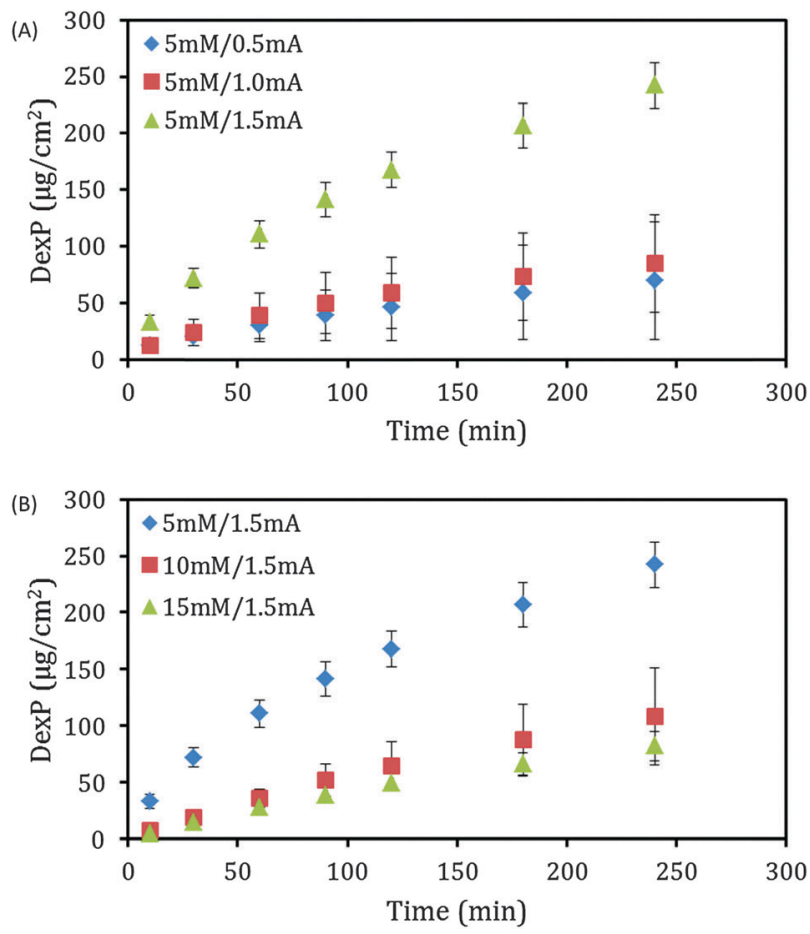

Fig. 6 DexP stimulated release profiles in artificial perilymph at room temperature of films polymerised at different current densities $(A)$ and with different DexP concentrations (B). $n=3$, error bars are representative of $95 \%$ confidence intervals around the mean. 

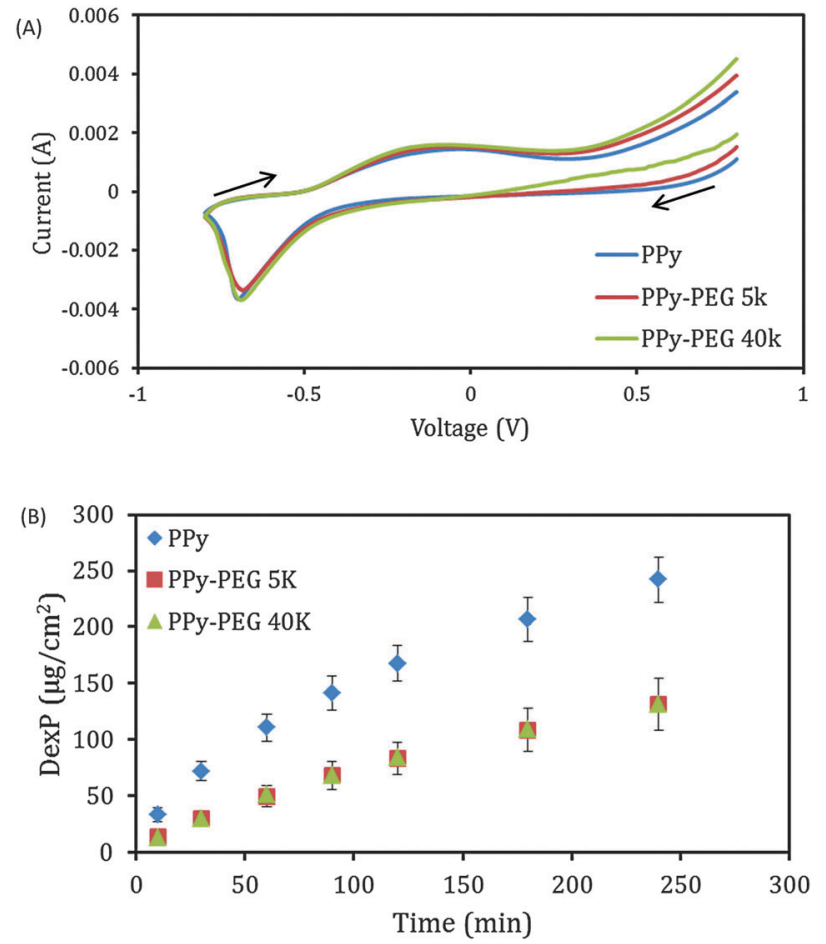

Fig. 7 (A) Cyclic voltammetry of PEG-SH modified and un-modified PPy/DexP films (5 mM/1.5 mA), performed in artificial perilymph at a scan rate of $10 \mathrm{mV} \mathrm{s}^{-1} \mathrm{vs}$. $\mathrm{Ag} / \mathrm{AgCl}$. The 1 st cycle is shown and the arrows indicate the direction of the potential scan. (B) DexP stimulated release from PEG-SH modified $5 \mathrm{mM} / 1.5 \mathrm{~mA}$ PPy/DexP films in artificial perilymph at room temperature for 4 hours. $n=3$, error bars are representative of $95 \%$ confidence intervals around the mean.

The $5 \mathrm{mM} / 1.5 \mathrm{~mA}$ PPy/DexP films were then chosen to be PEGylated for drug release studies. The PEG 5k and PEG 40k modified films showed almost identical DexP release profiles during the $4 \mathrm{~h}$ stimulation. However, the amount of DexP released from PEG-SH modified films were largely reduced (Fig. 7B). In a recent published study of PEGylation of ICPs, it is suggested that PPy is undergoing a reduction process during the thiol-ene reaction, and thus promote the release of mobile dopants out of the polymer films. ${ }^{30}$ The decreased DexP release therefore could be related to the loss of the DexP dopant during the PEGylation process. We tested the PEG solution after PEGylation and found UV absorption at $242 \mathrm{~nm}$ due to the presence of DexP. However, the PEGylation occurs predominately at the polymer surface where the PEG-SH molecules have access to the PPy polymer chains and therefore is not impacting the bulk polymer material. Therefore the loss of DexP during PEG modification is not expected to be detrimental to the drug delivery system. Furthermore, the CV analysis showed little change in the polymer electrochemical properties after PEGylation (Fig. 7A), demonstrating that the hydrophilic PEG layer does not affect the ion exchange at the PPy surface and hence the surface electroactivity. It could then be suggested that the decreased DexP release profile is more likely attributed to the initial loss of DexP from the PPy surface layer, and the slowed movement of DexP from within the bulk PPy film.

\section{Conclusion}

In this work, we have demonstrated the fabrication of a hybrid drug delivery system, with the capability of releasing an antiinflammatory agent as well as inhibiting protein adsorption at the polymer surface. By varying the conditions for electropolymerisation, such as current density and DexP concentration, PPy/DexP films with various surface morphology and mechanical properties were obtained. Consequently, these films exhibited different capability of $\mathrm{Fb}$ adsorption, surface reactivity to PEGylation, and DexP release profiles by electrical stimulation. PEG-SHs of two different molecular weight ( $5 \mathrm{kDa}$ and $40 \mathrm{kDa}$ ) were investigated for PEGylation of the PPy/DexP films. Both effectively inhibited the $\mathrm{Fb}$ adsorption at the resulting polymer surfaces, with the latter producing a more pronounced effect on protein resistance. All the PPy/DexP films demonstrated DexP release within 4 hours stimulation. The films prepared in $5 \mathrm{mM}$ DexP and at $1.5 \mathrm{~mA} \mathrm{~cm}{ }^{-2}$ released the largest amount of DexP after 4 hour stimulation.

The ability of PEGylation to reduce protein adsorption, while largely maintaining the polymer electro-activity, has significant implications for the development of drug eluting conducting polymer based devices, as well as development of low fouling conducting polymer based electrodes, which are currently the focus of intensive research activities for a diverse suite of biomedical applications.

\section{Acknowledgements}

The authors acknowledge the financial support of the HEARing Cooperative Research Centre, established and supported under the Cooperative Research Centres Program-Business Australia. The authors also thank the Australian Research Council (ARC) for continuing financial support (CE140100012). GGW is grateful to the ARC for support under the Australian Laureate Fellowship scheme (FL10100196). The authors acknowledge the support of the Australian National Fabrication Facility (ANFF). BZ would like to thank A/Prof Robert Cowan and Dr Carrie Newbold from the HEARing CRC for their advice.

\section{References}

1 G. Wallace and G. Spinks, Soft Matter, 2007, 3, 665-671.

2 R. T. Richardson, B. Thompson, S. Moulton, C. Newbold, M. G. Lum, A. Cameron, G. Wallace, R. Kapsa, G. Clark and S. O'Leary, Biomaterials, 2007, 28, 513-523.

3 C. E. Schmidt, V. R. Shastri, J. P. Vacanti and R. Langer, Proc. Natl. Acad. Sci. U. S. A., 1997, 94, 8948-8953.

4 A. Gelmi, M. J. Higgins and G. G. Wallace, Biomaterials, 2010, 31, 1974-1983.

5 G. G. Wallace, P. R. Teasdale, G. M. Spinks and L. A. KaneMaguire, Conductive electroactive polymers: intelligent polymer systems, CRC Press, 2008.

6 J. M. Anderson, A. Rodriguez and D. T. Chang, Semin. Immunol., 2008, 20, 86-100. 
7 J. A. Hamilton, J. Leukocyte Biol., 2003, 73, 702-712.

8 S. Franz, S. Rammelt, D. Scharnweber and J. C. Simon, Biomaterials, 2011, 32, 6692-6709.

9 C. J. Wilson, R. E. Clegg, D. I. Leavesley and M. J. Pearcy, Tissue Eng., 2005, 11, 1-18.

10 J. M. Anderson, Cardiovasc. Pathol., 1993, 2, 33-41.

11 P. J. Molino, G. G. Wallace and T. W. Hanks, Synth. Met., 2012, 162, 1464-1470.

12 M. Rodahl, F. Hook, A. Krozer, P. Brzezinski and B. Kasemo, Rev. Sci. Instrum., 1995, 66, 3924-3930.

13 M. Rodahl, F. Höök and B. Kasemo, Anal. Chem., 1996, 68, 2219-2227.

14 M. Rodahl and B. Kasemo, Rev. Sci. Instrum., 1996, 67, 3238-3241.

15 Y. Shen, J. Qiu, R. Qian and K. Carneiro, Die Makromolekulare Chemie, 1987, 188, 2041-2045.

16 P. J. Molino, P. C. Innis, M. J. Higgins, R. M. I. Kapsa and G. G. Wallace, Synth. Met., 2015, 200, 40-47.

17 P. J. Molino, B. Zhang, G. G. Wallace and T. W. Hanks, Biofouling, 2013, 29, 1155-1167.

18 M. Schirmeisen and F. Beck, J. Appl. Electrochem., 1989, 19, 401-409.
19 R. C. D. Peres, J. M. Pernaut and M.-A. De Paoli, J. Polym. Sci., Part A: Polym. Chem., 1991, 29, 225-231.

20 T. Silk, Q. Hong, J. Tamm and R. G. Compton, Synth. Met., 1998, 93, 59-64.

21 N. Gomez, J. Y. Lee, J. D. Nickels and C. E. Schmidt, Adv. Funct. Mater., 2007, 17, 1645-1653.

22 A. Kaynak, Mater. Res. Bull., 1997, 32, 271-285.

23 M. Heuberger, T. Drobek and J. Vörös, Langmuir, 2004, 20, 9445-9448.

24 S. Pasche, S. M. De Paul, J. Vörös, N. D. Spencer and M. Textor, Langmuir, 2003, 19, 9216-9225.

25 P. Harder, M. Grunze, R. Dahint, G. M. Whitesides and P. E. Laibinis, J. Phys. Chem. B, 1998, 102, 426-436.

26 P. Kingshott, H. Thissen and H. J. Griesser, Biomaterials, 2002, 23, 2043-2056.

27 I. Szleifer, Curr. Opin. Solid State Mater. Sci., 1997, 2, 337-344.

28 S. J. Sofia, V. Premnath and E. W. Merrill, Macromolecules, 1998, 31, 5059-5070.

29 K. L. Prime and G. M. Whitesides, J. Am. Chem. Soc., 1993, 115, 10714-10721.

30 B. Zhang, A. R. Nagle, G. G. Wallace, T. W. Hanks and P. J. Molino, Biofouling, 2015, 31, 493-502. 